\title{
Synthesis of ZnO-CuO Nanocomposite Aerogels by the Sol-Gel Route
}

\author{
Rula M. Allaf ${ }^{1}$ and Louisa J. Hope-Weeks ${ }^{2}$ \\ ${ }^{1}$ Department of Industrial Engineering, School of Applied Technical Sciences, German Jordanian University, \\ P.O. Box 35247, Amman 11180, Jordan \\ ${ }^{2}$ Department of Chemistry and Biochemistry, Texas Tech University, Lubbock, TX 79409-1061, USA
}

Correspondence should be addressed to Louisa J. Hope-Weeks; louisa.hope-weeks@ttu.edu

Received 18 July 2014; Revised 25 October 2014; Accepted 27 October 2014; Published 23 November 2014

Academic Editor: Qing Huang

Copyright (C) 2014 R. M. Allaf and L. J. Hope-Weeks. This is an open access article distributed under the Creative Commons Attribution License, which permits unrestricted use, distribution, and reproduction in any medium, provided the original work is properly cited.

\begin{abstract}
The epoxide addition sol-gel method has been utilized to synthesize porous zinc-copper composite aerogels in the zinc-to-copper molar ratios of 50:50 to 90:10. A two-step mixing approach has been employed to produce aerogels composed of nano- to micrometer sized particles. The aerogels were characterized by ultrahigh resolution scanning electron microscopy, transmission electron microscopy, and powder X-ray diffraction. The as-synthesized aerogels had a thin flake- or petal-like microstructure comprised of clustered flakes on two size scales; they were identified as being crystalline with the crystalline species identified as copper nitrate hydroxide, zinc hydroxide chloride hydrate, and zinc hydroxide nitrate hydrate. Annealing of the aerogel materials at a relatively low temperature $\left(400^{\circ} \mathrm{C}\right)$ resulted in a complete phase transition of the material to give highly crystalline $\mathrm{ZnO}$ $\mathrm{CuO}$ aerogels; the aerogels consisted of networked nanoparticles in the $\sim 25-550 \mathrm{~nm}$ size range with an average crystallite size of $\sim 3 \mathrm{~nm}$ and average crystallinity of $98 \%$. $\mathrm{ZnO}-\mathrm{CuO}$ aerogels are of particular interest due to their particular catalytic and sensing properties. This work emphasizes the versatility of this sol-gel route in synthesizing aerogels; this method offers a possible route for the fabrication of aerogels of different metal oxides and their composites.
\end{abstract}

\section{Introduction}

Aerogels are open-cell nanoporous materials composed of networks of interconnected nanoparticles typically produced by replacing the liquid of a gel by air or another gas without allowing collapse of the wet gel structure $[1,2]$. Their unique physical properties including low apparent density, large specific surface area, high thermal resistivity, low refractive index, and low dielectric constant give them the potential for a wide range of unique applications, such as in absorption, filtration, sensing, catalysis, thermal and acoustic insulation, electrodes for batteries, and capacitors as well as optics and light guides [2-5].

Aerogels are synthesized via two major steps, namely, low-temperature sol-gel processing and drying. They are essentially dried by supercritical drying, which allows the liquid of the gel to be extracted without collapsing the solid matrix from capillary action, and thus the dry samples retain the very porous texture they had in the wet state. Conversely, wet gels dried by evaporation result in compaction and loss of porosity, producing the so-called xerogels $[1,3-5]$. The epoxide addition sol-gel process has been demonstrated to be a relatively simple, inexpensive, and successful route to synthesize nontemplated monolithic metal oxide aerogels and xerogels [6-14] as well as nanocomposites [15-19]. Furthermore, variation of its processing parameters allows for control over the structure and properties of the resultant product [18, 20-22]. In this technique, metal oxide aerogels are synthesized using hydrated inorganic metal salts as metal precursors and epoxides as gelation initiators in aqueous or alcoholic media $[5,10]$.

The goal of the present work was to synthesize binary nanocomposite aerogels of zinc and copper (II) oxides ( $\mathrm{ZnO}$ $\mathrm{CuO}$ ) via the epoxide sol-gel method. $\mathrm{ZnO}$ is a wide band gap $(3.37 \mathrm{eV}) \mathrm{n}$-type semiconductor with a large exciton binding energy of $60 \mathrm{meV}[10,23]$ and piezoelectric properties 
TABLE 1: Synthesis conditions of $\mathrm{Zn}-\mathrm{Cu}$ composite gels at different molar ratios.

\begin{tabular}{lcccc}
\hline $\begin{array}{l}\text { Aerogel } \\
\text { designation }\end{array}$ & $\begin{array}{c}\text { Molar ratio } \\
\left(\mathrm{Zn}\left(\mathrm{NO}_{3}\right)_{2} \cdot 6 \mathrm{H}_{2} \mathrm{O}: \mathrm{CuCl}_{2} \cdot 2 \mathrm{H}_{2} \mathrm{O}\right)\end{array}$ & $\begin{array}{c}\text { Mass of } \\
\mathrm{Zn}\left(\mathrm{NO}_{3}\right)_{2} \cdot 6 \mathrm{H}_{2} \mathrm{O}(\mathrm{g})\end{array}$ & $\begin{array}{c}\text { Mass of } \\
\mathrm{CuCl}_{2} \cdot 2 \mathrm{H}_{2} \mathrm{O}(\mathrm{g})\end{array}$ & 0.044 \\
$\mathrm{Zn}-\mathrm{Cu}_{90: 10}$ & $90: 10$ & 0.689 & 0.088 & 1.8 \\
$\mathrm{Zn}-\mathrm{Cu}_{80: 20}$ & $80: 20$ & 0.612 & 0.219 & 1.8 \\
$\mathrm{Zn}-\mathrm{Cu}_{50: 50}$ & $50: 50$ & 0.383 & 0.8 & 1.8 \\
\hline
\end{tabular}

$[10,24,25]$. Its nanostructures are of particular interest for potential applications in sensors, catalysts, field emitters, light emitting diodes, solar cells, hydrogen storage, and information storage [23-26]. $\mathrm{CuO}$ is an important narrow band gap $(1.2 \mathrm{eV})$ p-type semiconductor with many applications in sensors, catalysis, batteries, high temperature superconductors, solar cells, and field emitters [24, 26, 27]. Composite nanostructures of these two wide and narrow band gap semiconductors may offer combined functionalities and open the way for new enhanced applications, such as photocatalysts [28-33], gas sensors [23, 34-37], humidity sensors [38], biosensors [39], and solar cells [40]. The photocatalytic activity of $\mathrm{ZnO}-\mathrm{CuO}$ nanocomposites was found much better compared to a pure $\mathrm{ZnO}$ photocatalyst under identical conditions [28-30]. Moreover, these semiconducting composite oxides provided tunable optical and electrical properties from those of pure $\mathrm{ZnO}$ to those of pure $\mathrm{CuO}$ [41]. It has been also postulated that a mixture of $\mathrm{CuO}$ and $\mathrm{ZnO}$ nanostructures could provide a potentially useful multifunctional gas sensor whereby selected sensitivity for certain gases could be realized by changing their ratio [23]. It has been reported that the sensitivity for CO gas detection was significantly improved for a composite $\mathrm{CuO}-\mathrm{ZnO}$ nanostructured film [34].

Nanostructured $\mathrm{ZnO}-\mathrm{CuO}$ composites have been synthesized by several methods, for instance, thermal decomposition $[24,28]$, coprecipitation methods [30, 33, 42], oxidizing brass in air [23] or in alkaline vapor [39], hydrothermal methods [29, 34, 37, 38], a hydrothermal method followed by photo-deposition [32], plasma-enhanced chemical vapor deposition followed by radio frequency sputtering [31, 36], sol-gel film coating methods [40,41], and thermal evaporation followed by impregnation [35]. Most methods included a final annealing step for the formation of the desired metal oxides [30-32, 35-37, 40-42]. Yet, to the extent of our knowledge there has been no study in the literature on the preparation of $\mathrm{ZnO}-\mathrm{CuO}$ nanocomposite aerogels.

Sol-gel techniques have distinct advantage of preparing homogeneous composite aerogels with excellent compositional control and lower crystallization temperature [18, 41]. Herein, we report the preparation of petal-like porous zinccopper composite aerogels via the epoxide addition sol-gel method in the zinc-to-copper salt molar ratios of $50: 50$ to $90: 10$; upon annealing the as-synthesized aerogels, $\mathrm{ZnO}$ $\mathrm{CuO}$ nanocomposites aerogels composed of networked nanoparticles were achieved.

\section{Experimental Procedure}

2.1. Aerogel Synthesis. Copper (II) chloride dihydrate, $\mathrm{CuCl}_{2} \cdot 2 \mathrm{H}_{2} \mathrm{O}$ (Fisher Scientific), zinc nitrate hexahydrate,
$\mathrm{Zn}\left(\mathrm{NO}_{3}\right)_{2} \cdot 6 \mathrm{H}_{2} \mathrm{O}$ (J. T. Baker), methanol (HPLC grade, Fisher Scientific), acetone (ACS grade, Mallinckrodt), 2-propanol (HPLC grade, Fisher Scientific), and propylene oxide (Alfa Aesar) were used as received without further purification. All syntheses were performed under ambient conditions. Gels were prepared by mixing solutions of zinc nitrate with solutions of copper (II) chloride. The total number of moles of metal salts in each gel was held constant at a salt-toepoxide molar ratio of 1:10 and utilizing $1.8 \mathrm{~mL}$ of epoxide, while the zinc-to-copper salt molar ratio was varied from $90: 10,80: 20$ to $50: 50$ as delineated in Table 1 . It is worth mentioning that the 1:10 salt-to-epoxide molar ratio was chosen based on previously reported successful gel formation and observed precipitation with insufficient epoxide-tometal ratio to drive the reaction through to gelation [10]. Aerogels were designated as $\mathrm{Zn}-\mathrm{Cu}_{x: y}$, where $x: y$ refers to the zinc-to-copper salt molar ratio.

In a typical experiment, $\mathrm{CuCl}_{2} \cdot 2 \mathrm{H}_{2} \mathrm{O}$ was dissolved in $6 \mathrm{~mL}$ 2-propanol giving a green solution. Propylene oxide (salt-to-epoxide molar ratio $1: 10$ ) was then added to the solution and the mixture was rapidly stirred resulting in a brownish solution. Subsequently, the solution was allowed to gel undisturbed for $\sim 1.5$ hours. $\mathrm{Zn}\left(\mathrm{NO}_{3}\right)_{2} \cdot 6 \mathrm{H}_{2} \mathrm{O}$ was dissolved in $2 \mathrm{~mL}$ methanol and propylene oxide (salt-toepoxide molar ratio 1:10) was added to the clear colorless solution. The mixture was rapidly stirred and immediately added to the gelling copper solution causing a color change to blue. Then the mixture was allowed to gel undisturbed. Following gelation, the gels were aged for $\sim 3-4$ days in closed vials under ambient conditions to improve the firmness of the gel [10]. The aged gels were then repeatedly washed with acetone for $\sim 10$ days to exchange the solvents with acetone. The acetone-filled gels were next supercritically dried in a SPIDRY critical point dryer (SPI Supplies, USA), where acetone was exchanged with liquid $\mathrm{CO}_{2}$ for 3-5 days, after which the temperature was increased to $40^{\circ} \mathrm{C}$ and then the dryer was slowly vented over a period of 4 hours to obtain $\mathrm{Zn}$ $\mathrm{Cu}$ composite aerogels. Aerogels were then heat-treated in a muffle furnace in ambient air. Four heat increments were met $\left(100,200,300\right.$, and $\left.400^{\circ} \mathrm{C}\right)$ at a rate of $1^{\circ} \mathrm{C} / \mathrm{min}$ with a dwell time of 2 hours before returning back to room temperature. The aerogels underwent color changes indicative of phase transformations as was demonstrated by XRD.

2.2. Aerogel Characterization. The surface morphologies of the aerogels were examined by scanning electron microscopy using a Hitachi S-5000 ultrahigh resolution field emission scanning electron microscope (UHRSEM, Hitachi, Japan) operated at an accelerating voltage of $2 \mathrm{kV}$. Aerogel samples were mounted on the SEM holder using an aluminum 


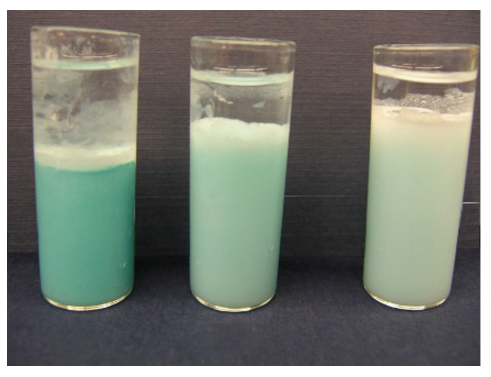

(a) (b)

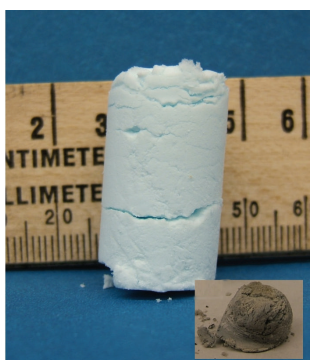

(d)

Figure 1: Photographs of (a) a $\mathrm{Zn}-\mathrm{Cu}_{50: 50}$ alcogel, (b) a $\mathrm{Zn}-\mathrm{Cu}_{80: 20}$ alcogel, (c) a $\mathrm{Zn}-\mathrm{Cu}_{90: 10}$ alcogel, and (d) a $\mathrm{Zn}-\mathrm{Cu}_{80: 20}$ aerogel illustrating the color, volume, and fragility of the monolithic aerogels. Inset figure shows a $400^{\circ} \mathrm{C}$ treated $\mathrm{Zn}-\mathrm{Cu}_{80: 20}$ aerogel.

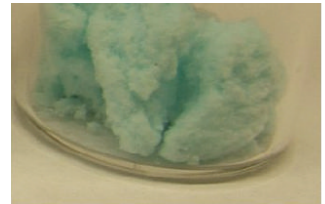

Room temperature

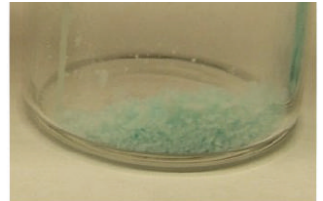

$100^{\circ} \mathrm{C}$

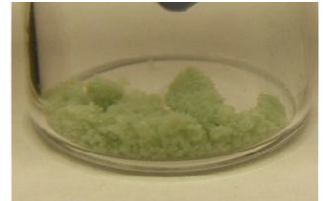

$200^{\circ} \mathrm{C}$

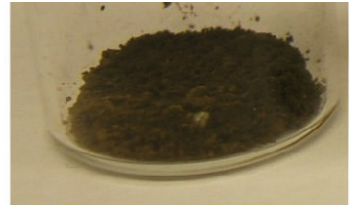

$300^{\circ} \mathrm{C}$

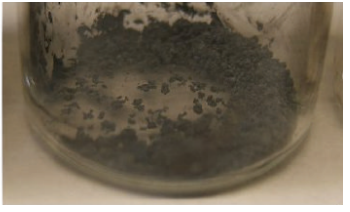

$400^{\circ} \mathrm{C}$

Figure 2: Photographs of $\mathrm{Zn}-\mathrm{Cu}_{80: 20}$ samples annealed at different temperatures illustrating color changes with annealing temperature.

stub with a double-sided carbon tape. Transmission electron microscopy micrographs were obtained using a Hitachi $\mathrm{H}-$ 8100 operating at $75 \mathrm{kV}$.

Powder X-ray diffraction data were collected on aerogel samples at room temperature using a Rigaku Ultima III X-ray powder diffractometer (Rigaku, Japan) utilizing $\mathrm{Cu} \mathrm{K} \alpha$ radiation $(40 \mathrm{kV}, 44 \mathrm{~mA})$. Phases were identified by comparison to digitized known phase patterns in the international center for diffraction data (ICDD) powder diffraction file (PDF) database and percent crystallinity was calculated using the MDI Jade 8 software program (Materials Data, Inc., USA).

\section{Results}

This modified epoxide sol-gel methodology, utilizing a twostep mixing approach, succeeded to produce composite aerogels at $90: 10,80: 20$, and $50: 50$ zinc-to-copper molar ratios. However, it should be mentioned here that the $20: 80$ and $10: 90$ ratios resulted in precipitation rather than gelation. The $\mathrm{Zn}-\mathrm{Cu}$ alcogels were light blue in color as shown in Figure 1 . The intensity of the blue color increased with copper content. Upon supercritical extraction, alcogels yielded their corresponding aerogels with no significant change in the gel appearance and with minimal loss in volume, which is clearly evident in Figure 1. However, the aerogels were fragile and removal of the monoliths from their vials resulted in some fracturing of the material as shown in Figure 1(d). From the visual inspection, the aerogels appeared homogeneous, with only occasional appearance of thin white aerogel top layers, which are most likely zinc gel dominated layers [10]. Upon annealing, the $\mathrm{Zn}-\mathrm{Cu}$ aerogels exhibited significant shrinkage and color changes as shown in Figures 1(d) and 2; at $200^{\circ} \mathrm{C}$, aerogels became light green with intensity of the green color increasing with copper content; then, at $300^{\circ} \mathrm{C}$, color transferred to brown following same intensity trends. Higher temperature annealing, at $400^{\circ} \mathrm{C}$, resulted in minor color changes with $\mathrm{Zn}-\mathrm{Cu}_{80: 20}$ turning grayish as demonstrated in Figure 2.

The morphology of the $\mathrm{Zn}-\mathrm{Cu}$ aerogels was evaluated using electron microscopy (Figures 3 and 4). As shown in Figure 3, HR-SEM micrographs clearly demonstrate that as-synthesized composite aerogels are composed of two homogeneously mixed clusters of thin flakes of two different size scales. As clearly evident in the high magnification inset in Figure 3(a), $\mathrm{Zn}-\mathrm{Cu}_{50: 50}$ has clusters composed of large, mostly uniform and circular, flakes on the $\sim 700-1200 \mathrm{~nm}$ size range and clusters composed of small flakes on the 80-130 nm scale. $\mathrm{Zn}-\mathrm{Cu}_{80: 20}$ (Figure 3(c)) and $\mathrm{Zn}-\mathrm{Cu}_{90: 10}$ (Figure 3(e)) smaller flakes are on approximately the same size scale as their equivalents in $\mathrm{Zn}-\mathrm{Cu}_{50: 50}$; however, their large flakes are irregular and on the $\sim 2-6 \mu \mathrm{m}$ size scale.

In reference to Figures 3(b), 3(d), and 3(f), aerogels annealed at $400^{\circ} \mathrm{C}$ appear to be composed of networked particles in the size range of $\sim 25-550 \mathrm{~nm}$, with $\mathrm{Zn}-\mathrm{Cu}_{50: 50}$ particles exhibiting smaller mean size, as seen in Figure 3(b). Several polygonized and spherical particles, as well as rodshaped particles, are clearly seen in the micrographs, Figures $3(\mathrm{~d})$ and 3(f), and are also evident in the transmission electron microscopy images, shown in Figures 4(b), 4(d), and 4(f). TEM micrographs further support several outcomes from the SEM micrographs, such as the thin flake microstructure of as-synthesized aerogels (flakes are transparent) and particle size range of aerogels.

The powder X-ray diffraction patterns for the assynthesized aerogels are shown in Figure 5. The assynthesized aerogels are crystalline; but it was difficult 


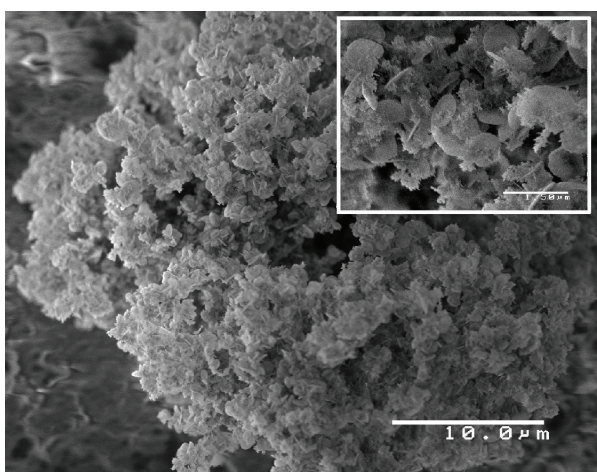

(a)

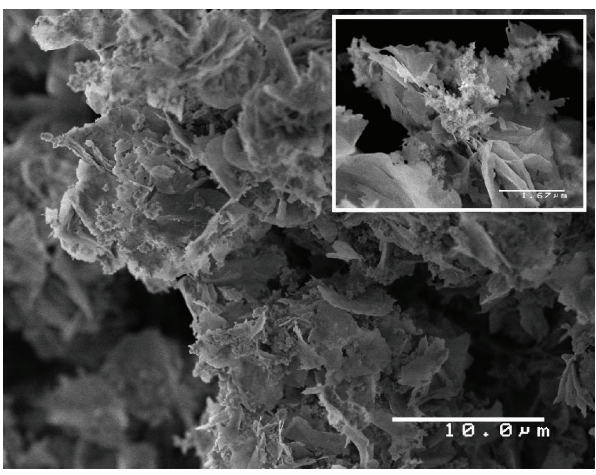

(c)

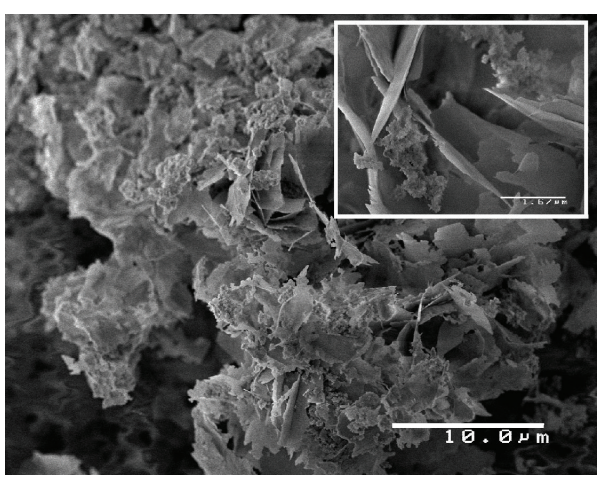

(e)

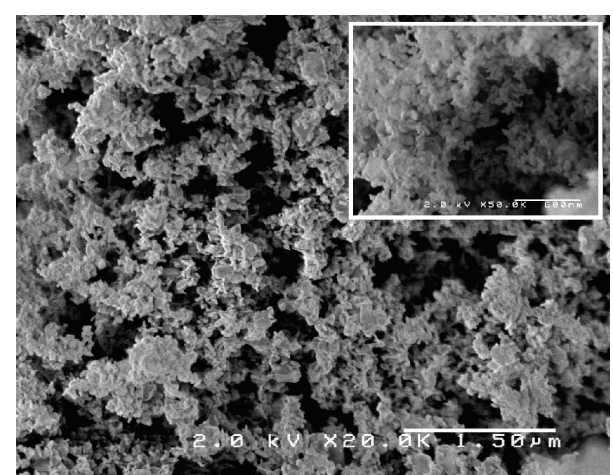

(b)

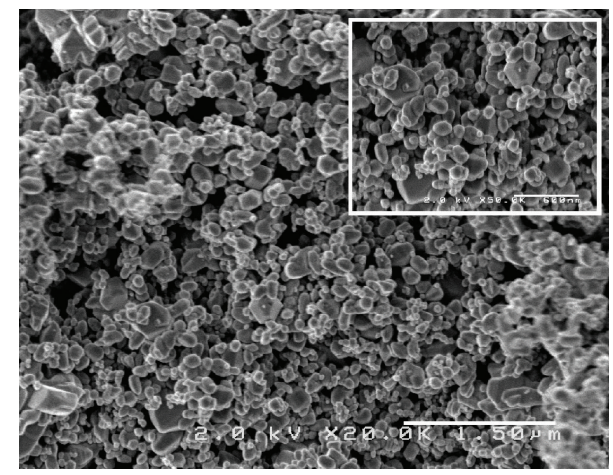

(d)

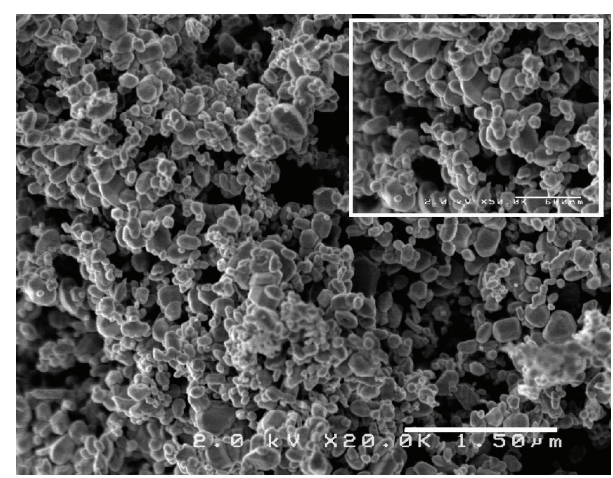

(f)

FIGURE 3: HR-SEM micrographs of as-synthesized and $400^{\circ} \mathrm{C}$ annealed (a, b) $\mathrm{Zn}-\mathrm{Cu}_{50: 50}$; (c, d) $\mathrm{Zn}-\mathrm{Cu}_{80: 20}$, and (e, f) $\mathrm{Zn}-\mathrm{Cu}_{90: 10}$ aerogels. Inset figures show higher magnification micrographs illustrating aerogel particles size and shape.

to assure phase identification. The primary phases in the $\mathrm{Zn}-\mathrm{Cu}_{50: 50}$ sample were best identified to be zinc hydroxide chloride hydrate, $\mathrm{Zn}_{5}(\mathrm{OH})_{8} \mathrm{Cl}_{2} \cdot \mathrm{H}_{2} \mathrm{O}$ (PDF File \# 00-0070155), and copper nitrate hydroxide, $\mathrm{Cu}_{2}\left(\mathrm{NO}_{3}\right)(\mathrm{OH})_{3}$ (PDF File \# 99-000-1329). Those in the $\mathrm{Zn}-\mathrm{Cu}_{80: 20}$ sample were best identified to be $\mathrm{Zn}_{5}(\mathrm{OH})_{8} \mathrm{Cl}_{2} \cdot \mathrm{H}_{2} \mathrm{O}$ (PDF File \# 01-072-1444), zinc hydroxide nitrate hydrate, $\mathrm{Zn}_{5}(\mathrm{OH})_{8}\left(\mathrm{NO}_{3}\right)_{2} \cdot \mathrm{H}_{2} \mathrm{O}(\mathrm{PDF}$ File \# 01-072-0627), and $\mathrm{Cu}_{2}\left(\mathrm{NO}_{3}\right)(\mathrm{OH})_{3}$ (PDF File \# 01-0751779). Finally, $\mathrm{Zn}-\mathrm{Cu}_{90: 10}$ major phases were best identified as $\mathrm{Zn}_{5}(\mathrm{OH})_{8}\left(\mathrm{NO}_{3}\right)_{2} \cdot \mathrm{H}_{2} \mathrm{O}$ (PDF File \# 01-072-0627) and $\mathrm{Cu}_{2}\left(\mathrm{NO}_{3}\right)(\mathrm{OH})_{3}$ (PDF File \# 99-000-1329).

The as-synthesized aerogels were annealed at four temperatures $\left(100,200,300\right.$, and $\left.400^{\circ} \mathrm{C}\right)$ to convert the aerogel hydroxides and hydrates to their zinc and copper oxide analogues. The powder X-ray diffraction patterns of samples annealed at the four specified temperatures are also shown in Figure 5. It can be seen that significant changes appeared at $200^{\circ} \mathrm{C}$ implying phase transitions, while intensity of peaks increased significantly at $300^{\circ} \mathrm{C}$ implying significant increase in crystallinity. The XRD patterns at $400^{\circ} \mathrm{C}$ are comparable for all three aerogels with all peaks assigned to either $\mathrm{ZnO}$ (PDF File \# 01-074-0534) or CuO (PDF File \# 01-0895899), as shown in Figure 6. The aerogels annealed at $400^{\circ} \mathrm{C}$ were highly crystalline, with percentage crystallinity values ranging from 97 to $99 \%$ and average crystallite size of 1.3 and $0.8-7.2 \mathrm{~nm}$ for the $\mathrm{ZnO}$ and $\mathrm{CuO}$, respectively. Table 2 summarizes the main information extracted from analyzing the XRD patterns. 


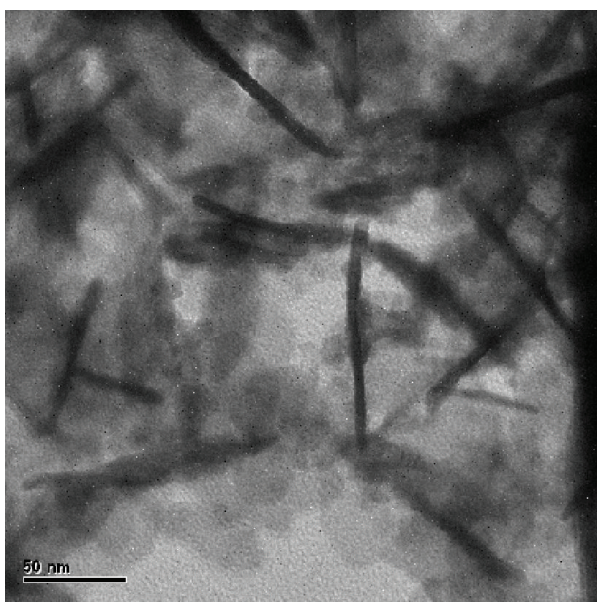

(a)

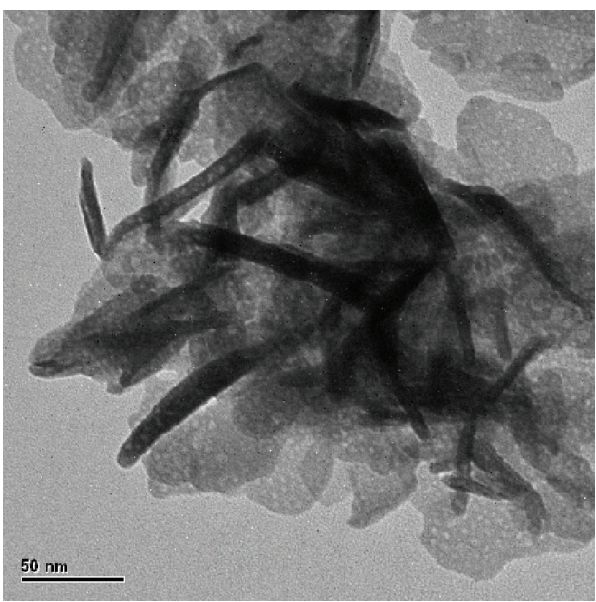

(c)

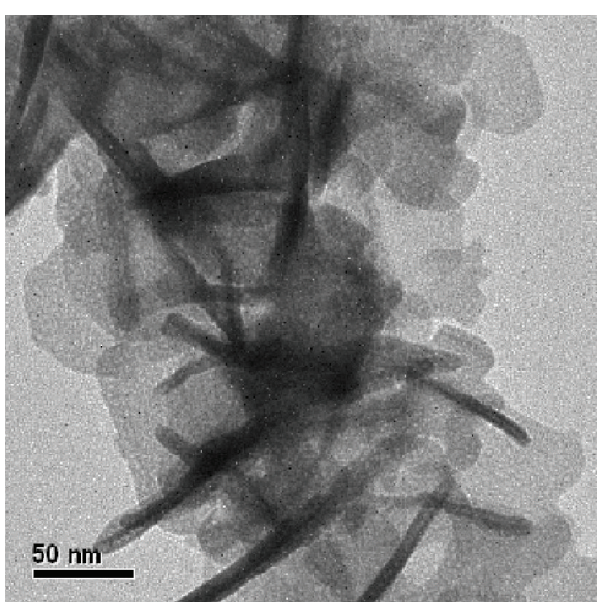

(e)

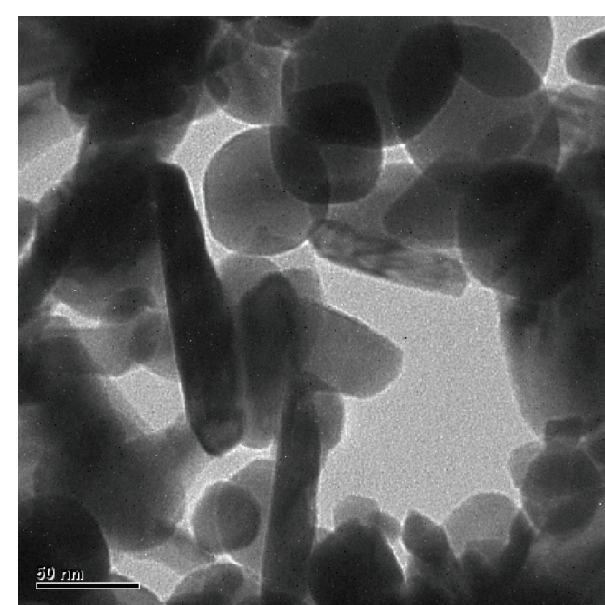

(b)

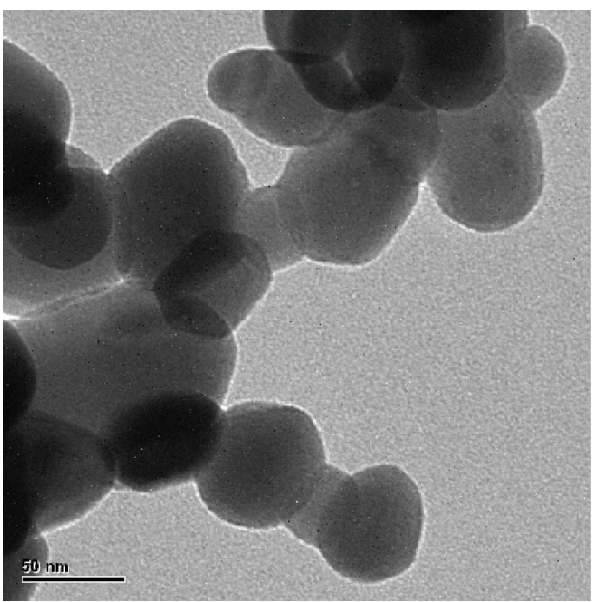

(d)

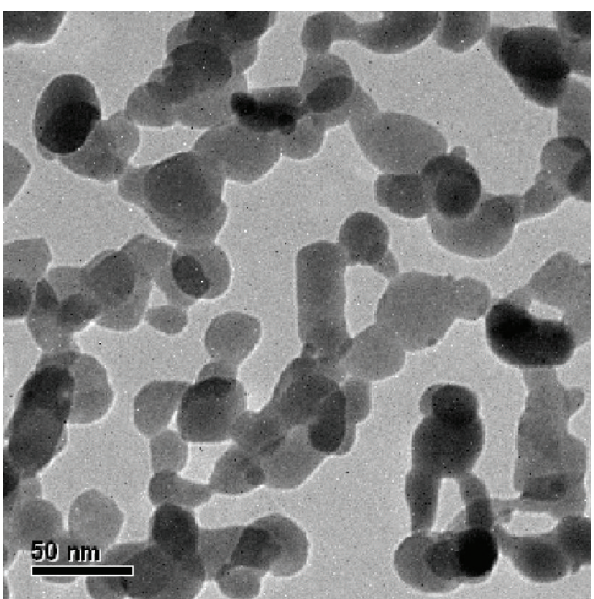

(f)

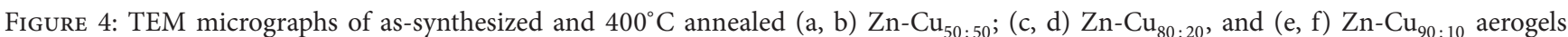
illustrating aerogel particles size and shape.

\section{Discussion}

Previous work successfully produced pure $\mathrm{ZnO}[10]$ and $\mathrm{CuO}$ [11] aerogels via the epoxide addition sol-gel method using zinc nitrate hexahydrate and copper (II) chloride dihydrate salts, respectively, with the most stable gels being formed in methanol and 2-propanol solvents, respectively. The gel time for synthesis in methanol was $8-10$ hours [10] whereas that 


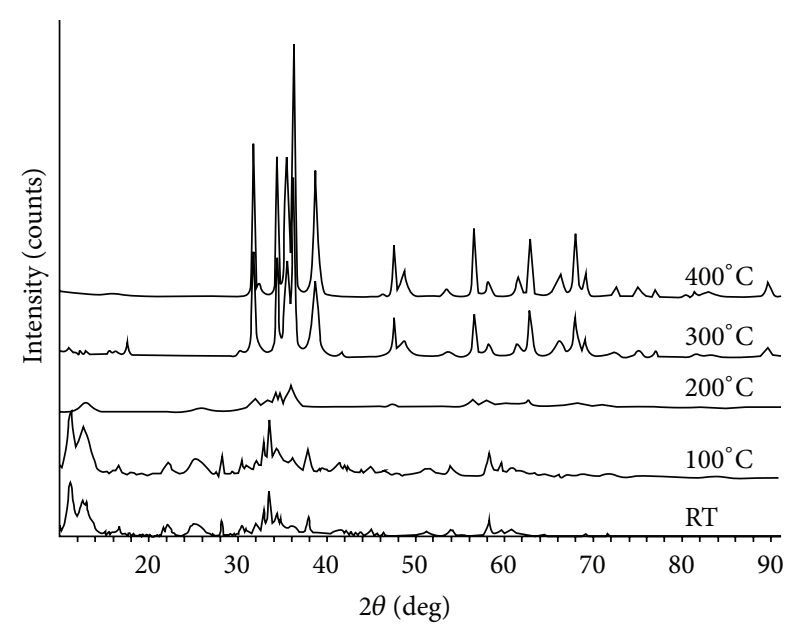

(a)

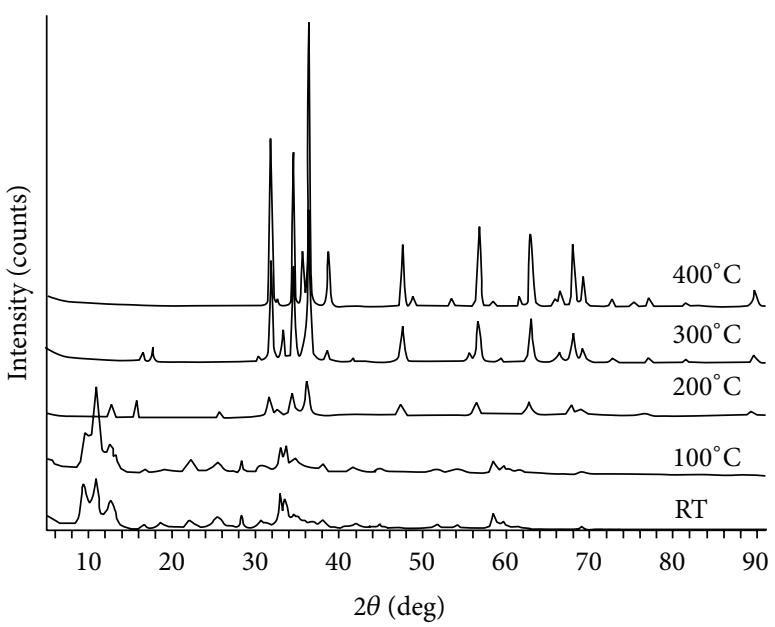

(b)

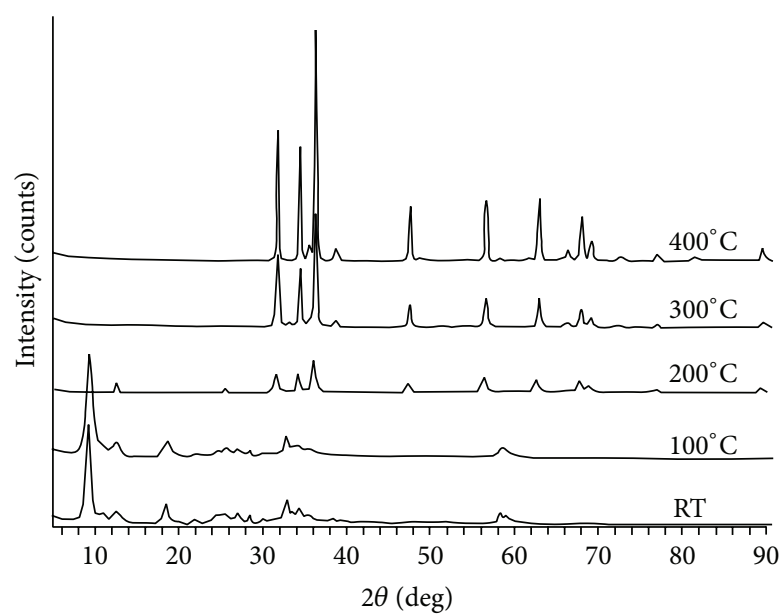

(c)

Figure 5: Powder X-ray diffraction data taken from as-synthesized (a) $\mathrm{Zn}-\mathrm{Cu}_{50: 50}$, (b) $\mathrm{Zn}-\mathrm{Cu}_{80: 20}$, and (c) $\mathrm{Zn}-\mathrm{Cu}_{90: 10}$ aerogels at room temperature (RT) and from four thermal treatments from 100 to $400^{\circ} \mathrm{C}$ illustrating phase transformations.

TABLE 2: XRD data from $\mathrm{Zn}-\mathrm{Cu}$ composite aerogels including predominant phases, crystallite size, and percentage crystallinity.

\begin{tabular}{|c|c|c|c|c|}
\hline $\begin{array}{l}\text { Aerogel } \\
\text { designation }\end{array}$ & $\begin{array}{c}\text { Annealing } \\
\text { temperature }\left({ }^{\circ} \mathrm{C}\right)\end{array}$ & Predominant phases & $\begin{array}{c}\text { Crystallite size } \\
(\AA)\end{array}$ & \% Crystallinity \\
\hline $\mathrm{Zn}-\mathrm{Cu}_{50: 50}$ & - & $\begin{array}{c}\mathrm{Zn}_{5}(\mathrm{OH})_{8} \mathrm{Cl}_{2} \cdot \mathrm{H}_{2} \mathrm{O} \text { and } \\
\mathrm{Cu}_{2}\left(\mathrm{NO}_{3}\right)(\mathrm{OH})_{3}\end{array}$ & 147, 190 & \\
\hline $\mathrm{Zn}-\mathrm{Cu}_{80: 20}$ & - & $\begin{array}{c}\mathrm{Zn}_{5}(\mathrm{OH})_{8} \mathrm{Cl}_{2} \cdot \mathrm{H}_{2} \mathrm{O} \\
\mathrm{Zn}_{5}(\mathrm{OH})_{8}\left(\mathrm{NO}_{3}\right)_{2} \cdot \mathrm{H}_{2} \mathrm{O} \\
\text { and } \mathrm{Cu}_{2}\left(\mathrm{NO}_{3}\right)(\mathrm{OH})_{3}\end{array}$ & $98,150,120$ & \\
\hline $\mathrm{Zn}-\mathrm{Cu}_{90: 10}$ & - & $\begin{array}{c}\mathrm{Zn}_{5}(\mathrm{OH})_{8}\left(\mathrm{NO}_{3}\right)_{2} \cdot \mathrm{H}_{2} \mathrm{O} \\
\text { and } \mathrm{Cu}_{2}\left(\mathrm{NO}_{3}\right)(\mathrm{OH})_{3}\end{array}$ & 136,150 & \\
\hline $\mathrm{Zn}-\mathrm{Cu}_{50: 50}$ & 400 & $\mathrm{ZnO}$ and $\mathrm{CuO}$ & 13,34 & $99 \%$ \\
\hline $\mathrm{Zn}-\mathrm{Cu}_{80: 20}$ & 400 & $\mathrm{ZnO}$ and $\mathrm{CuO}$ & 13,72 & $99 \%$ \\
\hline $\mathrm{Zn}-\mathrm{Cu}_{90: 10}$ & 400 & $\mathrm{ZnO}$ and $\mathrm{CuO}$ & 13,8 & $97 \%$ \\
\hline
\end{tabular}

for 2-propanol was $>24$ hours [11]. Furthermore, the gel times appeared to be dependent on the identity of the solvent [10]. In this study, several preliminary attempts to prepare $\mathrm{Zn}$ $\mathrm{Cu}$ composite aerogels by simultaneously dissolving different $\mathrm{Cu}$ and $\mathrm{Zn}$ precursors $\left(\mathrm{Zn}\left(\mathrm{NO}_{3}\right)_{2} \cdot 6 \mathrm{H}_{2} \mathrm{O}, \mathrm{ZnCl}_{2} \cdot 6 \mathrm{H}_{2} \mathrm{O}\right.$,
$\mathrm{CuCl}_{2} \cdot 2 \mathrm{H}_{2} \mathrm{O}, \mathrm{Cu}\left(\mathrm{NO}_{3}\right)_{2} \cdot 2.5 \mathrm{H}_{2} \mathrm{O}$, and $\left.\mathrm{Cu}\left(\mathrm{SO}_{4}\right) \cdot 5 \mathrm{H}_{2} \mathrm{O}\right)$ in different solvents previously reported to be successful in gel formation (methanol, 2-propanol, ethanol, and acetone [10, 11]) and mixtures of solvents at different metal salt concentrations and utilizing different metal-to-epoxide ratios $(1: 5,1: 10$, and 


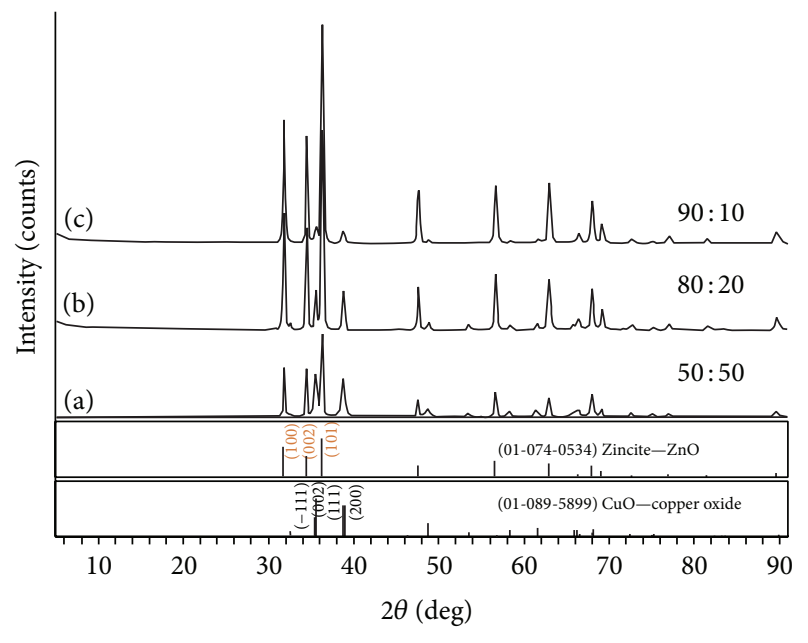

Figure 6: Powder X-ray diffraction data taken from (a) $\mathrm{Zn}-\mathrm{Cu}_{50: 50}$, (b) $\mathrm{Zn}-\mathrm{Cu}_{80: 20}$, and (c) $\mathrm{Zn}-\mathrm{Cu}_{90: 10}$ aerogels annealed at $400^{\circ} \mathrm{C}$ showing identified peaks.

$1: 20)$ all failed to cause gelation. It was hypothesized that adding the solution with the shorter gel time (zinc nitrate solution) to the longer gel time solution (copper (II) chloride solution) after the initiation of its gelation would allow gelation of such mixture systems that do not have a common gelation solvent, probably by distributing the second solution into the first gel during its transition process, which may provide a platform for deposition of a seed layer, which is important for the growth of nanostructures [34]. Successful gel formation was observed with the $90: 10,80: 20$, and $50: 50$ zinc-to-copper molar ratios by using this two-step synthetic strategy of the epoxide addition sol-gel method. However, the aerogels were fragile, similar to some results obtained in $[10,11]$.

The 20:80 and 10:90 zinc-to-copper molar ratios resulted in precipitation rather than gelation. This inability to successfully undergo the gel transition can be attributed to the differences in solubility and stability of the copper sol and/or the zinc sol in the various solvents $[10,11]$. In $[10,11]$ several factors were claimed important in stabilizing the gel transition: the chemical nature of the counter ion and solvent, the concentration of the metal salt, and the epoxideto-metal ratio. For example, only precipitation was observed at concentrations of the hydrated copper (II) chloride in 2propanol below $0.05 \mathrm{~mol} \mathrm{~L}^{-1}$ [11], and ethanol, 2-propanol, and acetone were determined to not be suitable solvents for the stability of the resultant $\mathrm{Zn}$ (II) aerogels [10].

Morphologies of the synthesized composites differed from morphologies of their individual constituents synthesized under similar conditions [10, 11]. As-synthesized composite aerogels appeared to be composed of two homogeneously mixed clusters of thin flakes (petals) of two different size scales. This flake- or petal-like structure was observed in $\mathrm{Zn}$ (II) aerogel synthesis under similar conditions [10]; however, as-synthesized $\mathrm{Cu}$ (II) aerogel showed aggregates of rough spherical particles with particle size ranging from 5 to $60 \mathrm{~nm}$ [11]. Reference [26] reported the synthesis of similar
$\mathrm{CuO}$ nanoflowers composed of several layers of leaf-like structure utilizing the chemical bath deposition method. The annealed composite aerogels showed smaller polygonized and spherical particles in addition to rod-shaped particles. Hexagonal but thin platelets were reported in annealed $\mathrm{ZnO}$ under similar conditions [10], whereas the reported annealed $\mathrm{CuO}$ aerogels were composed of dense clusters with rough and uneven particles [11]. Similar but largely aggregated irregular, spherical, and elongated (nanorods) $\mathrm{ZnO}-\mathrm{CuO}$ nanoparticles were reported in [24, 28, 40-42]; reference [28] conveyed elongations of nanorods with decreasing copper content: from an average length of $75 \mathrm{~nm}$ to $500 \mathrm{~nm}$ as copper salt content decreased from $50 \mathrm{wt} \%$ to $1 \mathrm{wt} \%$. Thus, it may be suggested that the polygonized particles and the nanorods are $\mathrm{ZnO}$ particles.

The primary crystalline phases in the as-synthesized aerogels were identified as $\mathrm{Cu}_{2}\left(\mathrm{NO}_{3}\right)(\mathrm{OH})_{3}, \mathrm{Zn}_{5}(\mathrm{OH})_{8} \mathrm{Cl}_{2} \cdot \mathrm{H}_{2} \mathrm{O}$, and $\mathrm{Zn}_{5}(\mathrm{OH})_{8}\left(\mathrm{NO}_{3}\right)_{2} \cdot \mathrm{H}_{2} \mathrm{O}$. With metal precursors being $\mathrm{CuCl}_{2} \cdot 2 \mathrm{H}_{2} \mathrm{O}$ and $\mathrm{Zn}\left(\mathrm{NO}_{3}\right)_{2} \cdot 6 \mathrm{H}_{2} \mathrm{O}$, a trend can be recognized with nitrate species dominating the gelation products and zinc chloride species appearing with increasing $\mathrm{CuCl}_{2} \cdot 2 \mathrm{H}_{2} \mathrm{O}$ metal precursor content. This could be attributed to higher affinity for the nitrate ion than for the chloride ion, and the different solution concentrations. The annealed aerogel materials $\left(400^{\circ} \mathrm{C}\right)$ were highly crystalline, with average crystallite size of $\sim 3 \mathrm{~nm}$ and diffraction peaks readily indexed to either $\mathrm{ZnO}$ or $\mathrm{CuO}$; relative $\mathrm{CuO}$ peak intensity increased with increasing copper concentration. The coexistence of the $\mathrm{CuO}$ and $\mathrm{ZnO}$ peaks in the XRD spectra confirms that the structure is a composite nanostructure.

To our knowledge, this is the first $\mathrm{ZnO}-\mathrm{CuO}$ nanocomposite aerogel of its kind. Previously, a variety of synthesis methods have produced various $\mathrm{ZnO}-\mathrm{CuO}$ nanostructures, such as equilateral spherical or polyhedral nanoparticles [24, 28, 40-42], nanowires [23, 34], nanorods [28], nanoflakes [23], ZnO nanoplates mixed with $\mathrm{CuO}$ nanoparticles [29], porous flower-like microstructures [37], flower-like $\mathrm{ZnO}$ microstructures and some leaf-like $\mathrm{CuO}$ nanopatches [33], and $\mathrm{CuO}$ nanoflowers on $\mathrm{ZnO}$ nanorods [39], in addition to hierarchal structures achieved by multistep fabrication techniques, for example, core-shell nanorods [31], corn-like nanorods [32], nanocorals [38], $\mathrm{CuO}$ decorating $\mathrm{ZnO}$ nanorods [31], $\mathrm{CuO}$ nanoparticles on $\mathrm{ZnO}$ nanotetrapod [35], and $\mathrm{CuO}$ nanoaggregates on $\mathrm{ZnO}$ nanorods [36]. Our results will further shed light on the fabrication of free-standing nanocomposite aerogels via the sol-gel route for their application in future multifunctional applications.

\section{Conclusions}

In conclusion, we have demonstrated the successful use of the epoxide addition method for the preparation of porous $\mathrm{Zn}$-Cu composite aerogels in the zinc-to-copper molar ratios of $50: 50$ to $90: 10$. As-synthesized aerogels were mixtures of networked flakes of two different size scales. Furthermore, we have shown that the as-synthesized composite aerogels could be converted to crystalline $\mathrm{ZnO}-\mathrm{CuO}$ aerogels by annealing the samples at $400^{\circ} \mathrm{C}$. Annealed aerogels consisted of networked nanoparticles in the size range of $\sim 25-550 \mathrm{~nm}$. Such 
porous $\mathrm{ZnO}-\mathrm{CuO}$ aerogels can have potential application in areas of catalysis and sensing. Finally, we have demonstrated that the epoxide addition sol-gel method offers a versatile route for the fabrication of homogeneous aerogels of different metal oxides composites in addition to the reported $\mathrm{CuO}$ $\mathrm{NiO}[18]$ and $\mathrm{ZnO}-\mathrm{SnO}_{2}$ aerogels [19].

\section{Conflict of Interests}

The authors declare that there is no conflict of interests regarding the publication of this paper.

\section{Acknowledgments}

The authors gratefully acknowledge the Texas Tech University Imaging Center, Department of Biological Sciences, for use of the Hitachi H-8100 and Hitachi S-5000; the authors also gratefully acknowledge the Department of Chemistry \& Biochemistry at Texas Tech University for use of the Rigaku Ultima III X-ray powder diffractometer.

\section{References}

[1] S. L. Brock, "Aerogels: disordered, porous nanostructures," in Nanoscale Materials in Chemistry, pp. 209-237, John Wiley \& Sons, Hoboken, NJ, USA, 2009.

[2] J. Kosny, T. Petrie, D. Yarbrough, P. Childs, A. M. Sayed, and B. Chris, "Nano-scale insulation at work: thermal performance of thermally bridged wood and steel structures insulated with local aerogel insulation," in Proceedings of 10th ASHRAE THERM, pp. 1-6, Clearwater, Fla, USA, 2007.

[3] N. Bheekhun, A. R. Abu Talib, and M. R. Hassan, "Aerogels in aerospace: an overview," Advances in Materials Science and Engineering, vol. 2013, Article ID 406065, 18 pages, 2013.

[4] J. L. Gurav, I.-K. Jung, H.-H. Park, E. S. Kang, and D. Y. Nadargi, "Silica aerogel: synthesis and applications," Journal of Nanomaterials, vol. 2010, Article ID 409310, 11 pages, 2010.

[5] A. C. Pierre and G. M. Pajonk, "Chemistry of aerogels and their applications," Chemical Reviews, vol. 102, no. 11, pp. 4243-4265, 2002.

[6] A. E. Gash, T. M. Tillotson, J. H. Satcher Jr., J. F. Poco, L. W. Hrubesh, and R. L. Simpson, "Use of epoxides in the sol-gel synthesis of porous iron(III) oxide monoliths from Fe(III) salts," Chemistry of Materials, vol. 13, no. 3, pp. 999-1007, 2001.

[7] A. E. Gash, J. H. Satcher Jr., and R. L. Simpson, "Monolithic nickel(II)-based aerogels using an organic epoxide: the importance of the counterion," Journal of Non-Crystalline Solids, vol. 350, pp. 145-151, 2004.

[8] T. F. Baumann, A. E. Gash, S. C. Chinn, A. M. Sawvel, R. S. Maxwell, and J. H. Satcher Jr., "Synthesis of high-surfacearea alumina aerogels without the use of alkoxide precursors," Chemistry of Materials, vol. 17, no. 2, pp. 395-401, 2005.

[9] C.-D. Park, D. Magana, and A. E. Stiegman, "High-quality Fe and $\gamma-\mathrm{Fe}_{2} \mathrm{O}_{3}$ magnetic thin films from an epoxide-catalyzed solgel process," Chemistry of Materials, vol. 19, no. 4, pp. 677-683, 2007.

[10] Y. P. Gao, C. N. Sisk, and L. J. Hope-Weeks, "A sol-gel route to synthesize monolithic zinc oxide aerogels," Chemistry of Materials, vol. 19, no. 24, pp. 6007-6011, 2007.
[11] C. N. Sisk and L. J. Hope-Weeks, "Copper(ii) aerogels via 1, 2epoxide gelation," Journal of Materials Chemistry, vol. 18, no. 22, pp. 2607-2610, 2008.

[12] P. Brown and L. J. Hope-Weeks, "The synthesis and characterization of zinc ferrite aerogels prepared by epoxide addition," Journal of Sol-Gel Science and Technology, vol. 51, no. 2, pp. 238-243, 2009.

[13] T. Y. Wei, C. H. Chen, K. H. Chang, S. Y. Lu, and C. C. Hu, "Cobalt oxide aerogels of ideal supercapacitive properties prepared with an epoxide synthetic route," Chemistry of Materials, vol. 21, no. 14, pp. 3228-3233, 2009.

[14] M. Davis, C. Gümeci, C. Kiel, and L. J. Hope-Weeks, "Preparation of porous manganese oxide nanomaterials by one-pot synthetic sol-gel method," Journal of Sol-Gel Science and Technology, vol. 58, no. 2, pp. 535-538, 2011.

[15] B. J. Clapsaddle, A. E. Gash, J. H. Satcher Jr., and R. L. Simpson, "Silicon oxide in an iron(III) oxide matrix: the sol-gel synthesis and characterization of $\mathrm{Fe}-\mathrm{Si}$ mixed oxide nanocomposites that contain iron oxide as the major phase," Journal of NonCrystalline Solids, vol. 331, no. 1-3, pp. 190-201, 2003.

[16] S. K. Gill, A. M. Shobe, and L. J. Hope-Weeks, "Synthesis of cobalt oxide aerogels and nanocomposite systems containing single-walled carbon nanotubes," Scanning, vol. 31, no. 3, pp. 132-138, 2009.

[17] S. K. Gill, P. Brown, M. T. Ogundiya, and L. J. Hope-Weeks, "High surface area alumina-supported nickel (II) oxide aerogels using epoxide addition method," Journal of Sol-Gel Science and Technology, vol. 53, no. 3, pp. 635-640, 2010.

[18] A. M. Shobe, S. K. Gill, and L. J. Hope-Weeks, "Monolithic CuO$\mathrm{NiO}$ aerogels via an epoxide addition route," Journal of NonCrystalline Solids, vol. 356, no. 25-27, pp. 1337-1343, 2010.

[19] M. Davis, W. M. Hikal, C. Gümeci, and L. J. Hope-Weeks, "Aerogel nanocomposites of $\mathrm{ZnO}-\mathrm{SnO}_{2}$ as efficient photocatalysts for the degradation of rhodamine B," Catalysis Science and Technology, vol. 2, no. 5, pp. 922-924, 2012.

[20] M. Davis, C. Gümeci, B. Black, C. Korzeniewski, and L. HopeWeeks, "Tailoring cobalt doped zinc oxide nanocrystals with high capacitance activity: factors affecting structure and surface morphology," RSC Advances, vol. 2, no. 5, pp. 2061-2066, 2012.

[21] P. Brown, D. U. Cearnaigh, E. K. Fung, and L. J. Hope-Weeks, "Controlling the morphology of a zinc ferrite-based aerogel by choice of solvent," Journal of Sol-Gel Science and Technology, vol. 61, no. 1, pp. 104-111, 2012.

[22] G. R. Peterson, F. Hung-Low, C. Gümeci, W. P. Bassett, C. Korzeniewski, and L. J. Hope-Weeks, "Preparation-morphologyperformance relationships in cobalt aerogels as supercapacitors," ACS Applied Materials and Interfaces, vol. 6, no. 3, pp. 1796-1803, 2014.

[23] Y. Zhu, C.-H. Sow, T. Yu et al., "Co-synthesis of $\mathrm{ZnO-CuO} \mathrm{nano-}$ structures by directly heating brass in air," Advanced Functional Materials, vol. 16, no. 18, pp. 2415-2422, 2006.

[24] M. Ghane, B. Sadeghi, A. R. Jafari, and A. R. Paknejhad, "Synthesis and characterization of a bi-oxide nanoparticle $\mathrm{ZnO} /$ $\mathrm{CuO}$ by thermal decomposition of oxalate precursor method," International Journal of Nano Dimensions, vol. 1, no. 1, pp. 3340, 2010.

[25] A. Janotti and C. G. van de Walle, "Fundamentals of zinc oxide as a semiconductor," Reports on Progress in Physics, vol. 72, no. 12, Article ID 126501, 29 pages, 2009.

[26] S. Zaman, Synthesis of $\mathrm{ZnO}, \mathrm{CuO}$ and their composite nanostructures for optoelectronics, sensing and catalytic applications [Ph.D. dissertation], Linköping University, Norrköping, Sweden, 2012. 
[27] L. Chen, S. Shet, H. Tang et al., "Electrochemical deposition of copper oxide nanowires for photoelectrochemical applications," Journal of Materials Chemistry, vol. 20, no. 33, pp. 6962-6967, 2010.

[28] R. Saravanan, S. Karthikeyan, V. K. Gupta, G. Sekaran, V. Narayanan, and A. Stephen, "Enhanced photocatalytic activity of $\mathrm{ZnO} / \mathrm{CuO}$ nanocomposite for the degradation of textile dye on visible light illumination," Materials Science and Engineering C, vol. 33, no. 1, pp. 91-98, 2013.

[29] T. Chang, Z. Li, G. Yun, Y. Jia, and H. Yang, "Enhanced photocatalytic activity of $\mathrm{ZnO} / \mathrm{CuO}$ nanocomposites synthesized by hydrothermal method," Nano-Micro Letters, vol. 5, no. 3, pp. 163-168, 2013.

[30] D. Zhang, "Photobleaching of pollutant dye catalyzed by p$\mathrm{n}$ junction $\mathrm{ZnO}-\mathrm{CuO}$ photocatalyst under UV-visible light activation," Russian Journal of Physical Chemistry A, vol. 87, no. 1, pp. 137-144, 2013.

[31] Q. Simon, D. Barreca, A. Gasparotto et al., "Vertically oriented $\mathrm{CuO} / \mathrm{ZnO}$ nanorod arrays: From plasma-assisted synthesis to photocatalytic $\mathrm{H}_{2}$ production," Journal of Materials Chemistry, vol. 22, no. 23, pp. 11739-11747, 2012.

[32] Z. Liu, H. Bai, S. Xu, and D. D. Sun, "Hierarchical CuO/ZnO "corn-like" architecture for photocatalytic hydrogen generation," International Journal of Hydrogen Energy, vol. 36, no. 21, pp. 13473-13480, 2011.

[33] B. Li and Y. Wang, "Facile synthesis and photocatalytic activity of $\mathrm{ZnO}-\mathrm{CuO}$ nanocomposite," Superlattices and Microstructures, vol. 47, no. 5, pp. 615-623, 2010.

[34] J. X. Wang, X. W. Sun, Y. Yang et al., "Free-standing ZnO$\mathrm{CuO}$ composite nanowire array films and their gas sensing properties," Nanotechnology, vol. 22, no. 32, Article ID 325704, 7 pages, 2011.

[35] N. Wu, M. Zhao, J.-G. Zheng et al., "Porous CuO-ZnO nanocomposite for sensing electrode of high-temperature CO solidstate electrochemical sensor," Nanotechnology, vol. 16, no. 12, pp. 2878-2881, 2005.

[36] Q. Simon, D. Barreca, A. Gasparotto et al., "CuO/ZnO nanocomposite gas sensors developed by a plasma-assisted route," ChemPhysChem, vol. 13, no. 9, pp. 2342-2348, 2012.

[37] J. Huang, Y. Dai, C. Gu, Y. Sun, and J. Liu, “Preparation of porous flower-like $\mathrm{CuO} / \mathrm{ZnO}$ nanostructures and analysis of their gassensing property," Journal of Alloys and Compounds, vol. 575, pp. 115-122, 2013.

[38] A. Zainelabdin, G. Amin, S. Zaman et al., "CuO/ZnO Nanocorals synthesis via hydrothermal technique: growth mechanism and their application as Humidity Sensor," Journal of Materials Chemistry, vol. 22, no. 23, pp. 11583-11590, 2012.

[39] T. Soejima, K. Takada, and S. Ito, "Alkaline vapor oxidation synthesis and electrocatalytic activity toward glucose oxidation of $\mathrm{CuO} / \mathrm{ZnO}$ composite nanoarrays," Applied Surface Science, vol. 277, pp. 192-200, 2013.

[40] M. H. Habibi, B. Karimi, M. Zendehdel, and M. Habibi, "Fabrication, characterization of two nano-composite $\mathrm{CuO}-\mathrm{ZnO}$ working electrodes for dye-sensitized solar cell," Spectrochimica Acta A: Molecular and Biomolecular Spectroscopy, vol. 116, pp. 374-380, 2013.

[41] Y. Caglar, D. D. Oral, M. Caglar et al., "Synthesis and characterization of $(\mathrm{CuO})_{x}(\mathrm{ZnO})_{1-x}$ composite thin films with tunable optical and electrical properties," Thin Solid Films, vol. 520, no. 21, pp. 6642-6647, 2012.
[42] J. Gajendiran and V. Rajendran, "Synthesis and characterization of coupled semiconductor metal oxide $(\mathrm{ZnO} / \mathrm{CuO})$ nanocomposite," Materials Letters, vol. 116, pp. 311-313, 2014. 

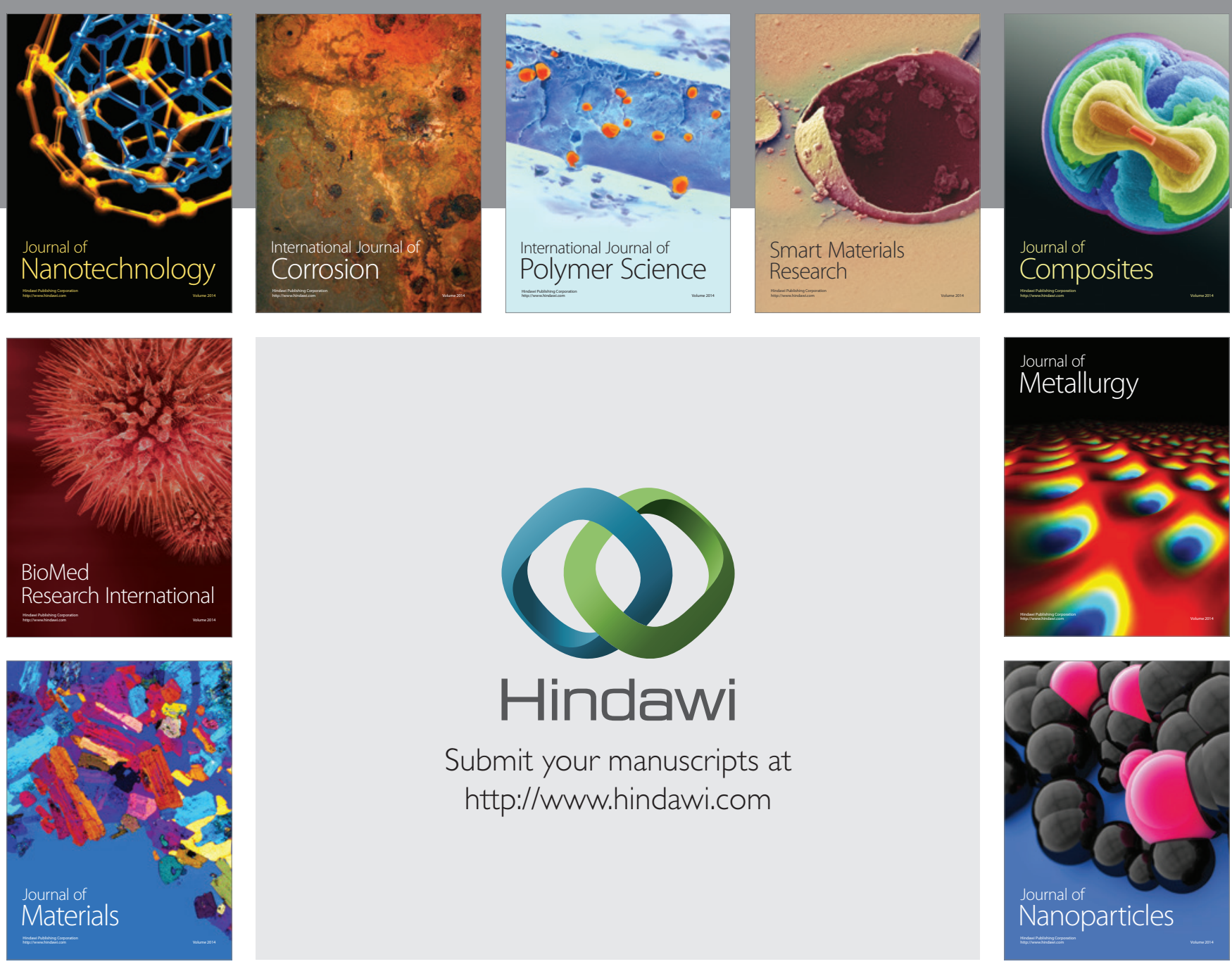

Submit your manuscripts at http://www.hindawi.com
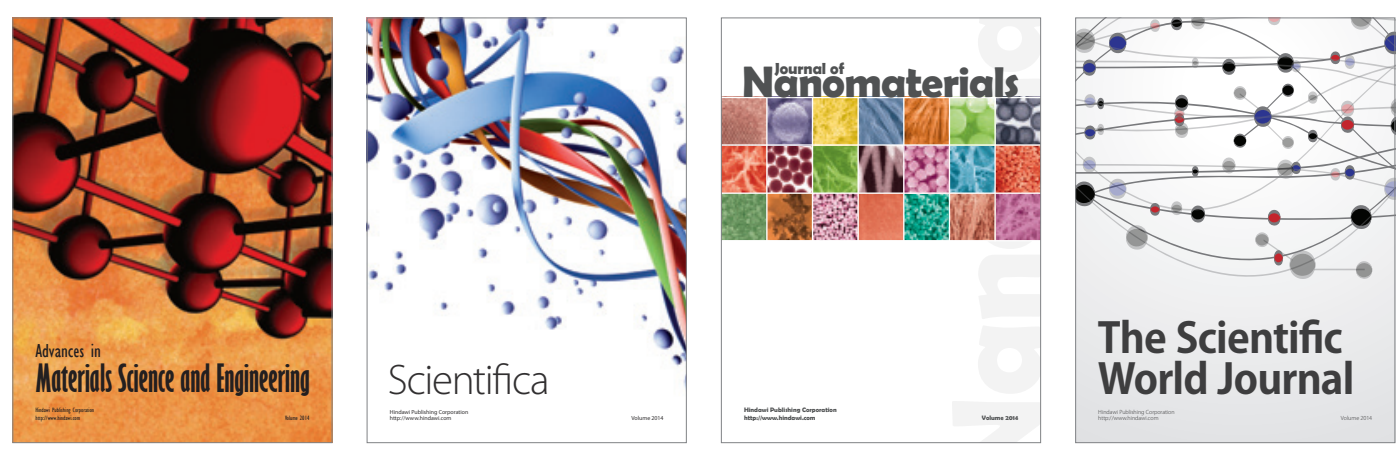

\section{The Scientific World Journal}
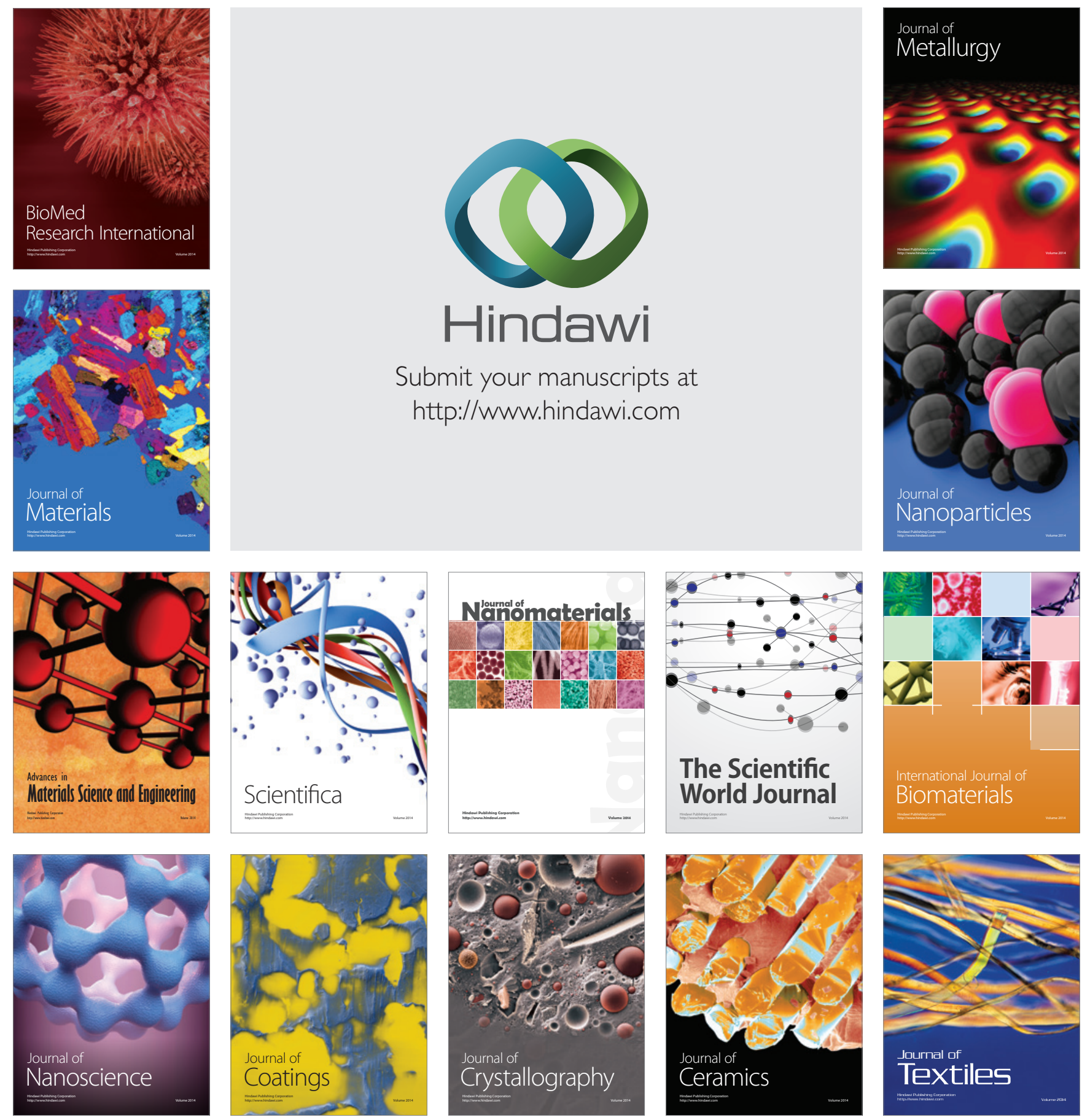